\title{
Centenário do Professor Penildon Silva
}

Todos aqueles que tiveram o privilégio de conviver com o Professor Penildon Silva certamente são capazes de testemunhar que este ilustre Professor estampava de forma muito expontânea, as características de um verdadeiro educador, reveladas nas concepções de educação e de ensino sempre presentes nos seus discursos. Segundo o Professor Penildon, "...a estratégia da aprendizagem deve iniciar-se na alegria e florescer no deslumbramento", ensinando que, "da interação professor-aluno, a transferência do conhecimento se faz com o impulso do entusiasmo e o desafio das interrogações."

Sobre a arte de ensinar, afirmou, com sabedoria:

Ensinar e aprender não se assemelham a induzir uma reação química. Seriam mais como pintar um quadro, compor uma música ou, em planos mais simples, plantar um jardim ou escrever uma carta amiga.

E, finalmente, há que se destacar a primorosa asserção:

Muito do conteúdo formal das várias disciplinas pode ser transmitido pelas máquinas e computadores, como, por exemplo, tabelas, fórmulas, classificações, etc. Entretanto, a relação entre as partes, as suposições de causas e efeitos, a criação de hipóteses, isto tudo constitui a porção mais delicada da formação intelectual e só pode ser resolvida pelo professor que tem imaginação. A imaginação preenche o espírito, anima o professor e delicia os alunos."

O Professor Penildon nasceu em 26 de março de 1921 na Cidade do Salvador, tendo se diplomado em Farmácia pela Universidade Federal da Bahia, por influência do seu pai, Sr. Pedro Silva, farmacêutico estabelecido em Salvador, a quem auxiliava, desde os 12 anos de idade, na manipulação de fórmulas e atendendo ao público nos balcões da farmácia. Com o passar dos anos veio a se graduar em Medicina também pela Universidade Federal da Bahia, e se pós-graduar em Saúde Pública pelo Instituto de Higiene na cidade de São Paulo.

Em 1942 foi trabalhar na empresa Rhodia, inicialmente como representante, muito embora tenha ficado por pouco tempo nesta função, sendo convidado a assumir a área de publicações científicas. Ao retornar de São Paulo passou a trabalhar como assessor médico desta Empresa, criando e desenvolvendo o antigo SEPETE - Serviço de Pesquisas Terapêuticas - embrião da pesquisa médica da Rhodia no Brasil, instituição na qual permaneceu durante 37 anos.

O Professor Penildon iniciou a sua carreira docente na Faculdade de Medicina da Universidade Federal da Bahia em 1956 lecionando Biofísica, Bioquímica e Farmacologia a diversos cursos como Enfermagem, Nutrição, Medicina Veterinária e Farmácia, além do curso de Medicina. Ressalte-se que, além de atuar na UFBA também lecionou por 30 anos, como Professor Convidado na Escola Bahiana de Medicina e Saúde Pública, contribuindo na formação dos profissionais diplomados naquela Instituição.

Participou da fundação do Instituto de Ciências da Saúde da Universidade Federal da Bahia juntamente com ilustres lideranças acadêmicas da época. Como Professor Titular, integrou o corpo docente do Departamento de Bioquímica do qual foi seu terceiro Chefe - de 1973 a 1975. Com a redepartamentalização do Instituto em 1976, o Prof. Penildon Silva passou a compor o Departamento de Biorregulação, instituição acolhedora dos diversos componentes curriculares das matérias de Farmacologia e Fisiologia. Foi eleito Vice-diretor do Instituto de Ciências da Saúde de 1976 e 1980, vindo, posteriormente, a ser eleito seu Diretor para o cumprimento de um mandato de quatro anos de 1980 a 1984.

Há que se reafirmar que existem tradições que não ferem a modernidade, ao contrário, enriquecem-na. No campo da ciência e do fazer acadêmico, consagrou-se a cultura da homenagem a seus mais ilustres representantes através do título de emérito, e deve sê-lo, uma vez que o conhecimento da história de uma instituição e dos que a fizeram constitui fonte de estímulo para as gerações de jovens estudantes que nela ingressam para continuar sua história.

Assim sendo, foi mais do que merecida a concessão do título de Professor Emérito da Universidade Federal da Bahia em outubro de 1993, ao Prof. Penildon Silva. Naquela ocasião o saudoso Professor Heonir Rocha proferiu um belo discurso de saudação do qual se destaca o seguinte trecho:

Se me perguntassem quais as características do nosso homenageado que mais se ajustam à sua obra, diria que ele cultivou a sobriedade como consequência de sua sabedoria; deixou que sua inquietude constante se manifestasse com suavidade, educação e elegância; demonstrou sua pertinácia e seu 
espírito de luta; cresceu e purificou-se nas provações do sofrimento físico; finalmente, continua sendo um entusiasmado pela vida acadêmica...

Há que se destacar que o Professor Penildon se dedicou intensamente ao trabalho de construção do compêndio intitulado "Farmacologia", contando com a colaboração de outros docentes, e sempre com a participação marcante de ex-alunos. Esse livro tornou-se um clássico que acompanhou e ainda acompanha várias gerações de estudantes da área de saúde no Brasil. Ao longo dos anos, o eminente Professor se dedicou a fazer várias atualizações da sua obra, cuja principal característica é a clareza e a didática como os conteúdos são apresentados. Além do livro de Farmacologia, o Prof. Penildon Silva teve mais de cinquenta publicações em periódicos nacionais e internacionais, tendo participado de semelhante número de congressos e de reuniões científicas no Brasil e no exterior. Participou ainda, da tradução de livros de farmacologia, tendo supervisionado a tradução do clássico Pharmacological Basis of Terapeutics de Goodman e Gilman.

Registre-se que foi extremamente oportuna a homenagem ao centenário do Professor Penildon Silva prestada de forma compartilhada pela Universidade do Estado da Bahia e a Universidade Federal da Bahia através do evento científico denominado Simpósio de Farmacologia: 100 anos do Professor Penildon Silva. Igualmente oportuna foi a mudança da denominação do Auditório da Congregação do Instituto de Ciências da Saúde que passou a se chamar "Auditório Professor Penildon Silva", aprovada em reunião da Congregação, realizada em 18 de março de 2021, presidida pelo Diretor Roberto Paulo C. de Araújo, Editor deste Periódico. Desta forma, ficou registrado o seu centenário de nascimento num ato de reconhecimento público que preserva a memória institucional e a importância deste ilustre Professor, seu legado intelectual para a Universidade e para a formação de várias gerações de profissionais da área biomédica.

Apesar de ter se aposentado em 1988, o Professor Penildon permaneceu frequentando diariamente o Instituto por muitos anos, colaborando na ministração de aulas de Farmacologia e em orientações científicas e, até mesmo, acolhendo e aconselhando a todos aqueles que o procuravam na busca de soluções de questões para as quais ele, com a sua experiência, conhecimento e sensibilidade, sempre vislumbrava uma alternativa eficiente.

Ao concluir este texto há de se acalentar a esperança de ter-se assegurado àqueles que não tiveram a oportunidade de conhecê-lo, pessoalmente, ter podido aproximá-los um pouco do seu pensamento através do recorte de trechos do seu discurso de posse como Professor Emérito da Universidade Federal da Bahia.

Não devemos recear a liberação de velhos costumes e velhos pensamentos. Não devemos ser pobres cópias de outras universidades.

Devemos ousar e trilhar novas linhas e assumir novas atitudes. Temos potenciais e problemas próprios que exigem soluções locais e originais.

Entre o banal e o repetitivo, que constituem o dia-a-dia, pode a Universidade de acordo com a sua grandeza intrínseca, criar, renovar, transformar, revolucionar e humanizar.

Profa. Dra. Lília Ferreira de Moura Costa

Professora Associada

Departamento de Biointeração

Instituto de Ciências da Saúde

Universidade Federal da Bahia 